\title{
SÖYLENCE İLE GERÇEKLİK ARASINDA: 19. YÜZYIL OSMANLI MIZAH BASININDA KARAFERYE CADILARI
}

\section{Gökhan DEMİRKOL *}

Öz

Osmanlı Devleti'nde ölümden sonra hayata dönen varlıklara ilişkin temel tanımlama "cadı" kavramıdır. Ancak konu hakkında yapılan çalışmalar genellikle "cadı" kavramını "vampir" kavramı ile açıklama eğilimindedir. Bu eğilimin temel sebebi ise 19. yüzyılın son çeyreğinde "cadı" kavramının anlamında yaşanan genişlemedir. Temel özellikleri benzer olan bu iki kavram toplumsal hayatta aynı olguyu tanımlamak için birbirlerinin yerine kullanılmıştır. 19. yüzyılda Osmanlı topraklarında kayıt altına alınmış son "cadı" olayı Tırnova cadılarıdır. Fakat 1872 ve 1874 yıllarında Selanik'e bağlı Karaferye'de iki cadı vakasının yaşandığına dair gazete haberleri bulunmaktadır. Bu çalışma bahsi geçen haberlere ilişkin dönemin gazete ve dergilerinin yaklaşımını ele almaktadır. Çalışmanın odağı mizah dergileridir. 19. yüzyılın ikinci yarısında Osmanlı toplumunda "cadı" kavramının hangi kavramlar ile tanımlandığı mizah dergileri üzerinden analiz edilmiştir.

Anahtar Kelimeler: Cadı, Karaferye, Osmanlı Mizah Basını

${ }^{*}$ Dr.Öğr. Üyesi, Çankırı Karatekin Üniversitesi, ORCID: 0000-0003-0672-0992 


\title{
Between Myth and Reality: Karaferye Witches in 19th Century Ottoman Humor Press
}

\begin{abstract}
The basic definition of the creatures that came to life after death in the Ottoman Empire is the concept of "witch". However, studies on this subject tend to explain the concept of "witch" with the concept of "vampire". The main reason for this tendency is the expansion in the meaning of the concept of "witch" in the last quarter of the 19th century. These two concepts, whose basic characteristics are similar, are used interchangeably to define the same phenomenon in social life. The last witch event recorded in the Ottoman lands in the 19th century is the "Witches of Veliko Tarnova". However, in that century there are news that two witch cases took place in Karaferye of Thessaloniki in 1872 and 1874. This study deals with the approach of newspapers and magazines of the period related to the mentioned news. The focus of the study is humor magazines. In the second half of the 19th century, the concepts of the definition of "witch" concept in Ottoman society were analyzed through humor magazines.
\end{abstract}

Keywords: Witch, Karaferye, Ottoman Humor Press.

\section{Giriş}

Merkezine "ölümden sonra yaşam" olgusunu yerleştiren ve olağanüstü nitelikler atfedilen varlıklara ilişkin inanç anlatıları, her toplumda gözlemlenen bir olgudur. Türk toplumu da benzer anlatılar açısından zengin bir literatüre sahiptir. Bu literatür içerisinde doğaüstü güçlere sahip olağanüstü nitelikler sergileyen varlıkları tanımlamak için halk anlatılarında pek çok kavrama rastlamak mümkündür. "Kara koncolas"tan "cadı"ya "vampir"den "hortlak"a pek çok farklı isme ve özelliğe sahip bu varlıklara ilişkin halk anlatıları nesilden nesile aktarılan sözlü kültürün bir parçası olmasının yanı sıra gündelik hayat pratiklerine ve gündelik dile de sirayet etme gücüne sahiptir. 
Doğaüstü varlıklara dair var olan literatür genellikle kayıt altına alınmış olayları batı tarzı "vampir" ile kıyaslayarak ya da olayların öznesi olan doğaüstü varlıkları "vampir" olgusu ile ilişkilendirerek değerlendirmektedir. Ancak Osmanlı Devleti'nde 19. yüzyıla kadar kayıt altına alınmış olaylar incelendiğinde ölümden sonra tekrar canlanan varlıklara ilişkin yaygın kullanılan kavramın "cadı" olduğu görülmektedir. Farsça "cadu" kelimesinden gelen "cadı"; "avamın itikad-i câhilânesince gûyâ mezardan çıkıp geceleri bir sûret-i mahufede ve cin gibi gezen hayal, vampir, kara koncolos, bed-huy ve bed-lika kocakarı, acûze" (Şemsettin Sami, 362) anlamına gelmektedir. Boratav ise "cadı"yı hortlayan ölü olarak tanımlayarak batı inanışındaki vampiri karşıladığını belirtir (Boratav, 1984, 79). 19. yüzyılın sonundan itibaren "cadı" kavramının "vampir" kavramı etrafında tanımlanması ve tanımlamanın süreklilik göstermesi konuya ilişkin var olan literatürün "cadı" ile "vampir" olgularını eşleştirdiğini göstermektedir. Ancak bu eşleştirmenin kaynağ belirsizdir. James W. Redhouse'un 1842 yılında yayıma hazır hale getirdiği ancak 1852-53 yıllarında basımı yapılan Müntahabât-ı Lügât-ı Osmâniyye'ye göre "cadı" kelimesini "sihirbaz, sâhir, sihir edici" (Redhouse, 2016, 49) şeklinde tanımlanmış iken 1890 tarihinde yayımlanmış Türkçe-İngilizce sözlükte Redhouse, "cadı" kelimesi "büyücü, cadı, büyücülük, büyü, güzel göz, acuze, uyuyan kişilerin kanını emmek için dünyaya döndüğü batıl bir inanç olarak varsayılan ölü kişi, vampir" (Redhouse, 1890, 634) biçiminde tanımlamıştır. "Cadı" kelimesinin anlamlarının arasına "vampir" kavramının girmesi kelimenin tarihsel süreç içerisinde bir anlam genişlemesi yaşadığına işaret etmektedir ki var olan literatürün bu anlam genişlemesi sonucu "cadı" ile "vampir" kavramlarını eşleştirdiği ileri sürülebilir. Bu durumun sebebini kültürel geçişlilik olarak açılklamak mümkündür. Batı'da 18. yüzyılda yaşanan vampir çılgınlığının sonucu olarak benzer doğaüstü varlıklara verilmiş isimlerin önüne geçerek bir "şemsiye" terim haline dönüşen "vampir" kavramı (Bkz. Kırgi, 2018, 91-101; Ayrıca bkz. Yaltırak, 2013, 191- 
192), 19. yüzyılın ikinci yarısında Osmanlı toplumunda da benzer varlıklar için kullanılan "cadı" tanımlaması ile karşılanır hale gelmiştir. Kültürel geçişliliğin yanı sıra Osmanlı toplumunda yer alan "cadı" inancının ya da tanımlamasının temel niteliğinin ölümden sonra "hortlamak" olduğu göz önüne alındığında batı tarzı "vampir" ile açıklanması doğaldır ki "vampir" olarak tanımlanan olgunun temel özelliği de "(...) doğa kanunlarına karşı gelerek yaşama dönen ölü insanlar(...)" (Kırgi, 2018, 9-10) olmasıdır.

"Cadı" ya da "vampir" şeklinde farklı isimlerle tanımlanan doğaüstü varlıklara ilişkin söylemler/hikayeler/anlatılar toplumun her dönem ilgisini çekmiştir. Osmanlı toplumunun 19. yüzyılda tanıştığı süreli yayınlar da bu tarz hikaye ve anlatılara ilgi göstermiş ve sayfalarında yer vermişlerdir. Bu duruma en iyi örnek 1833 yılında Takvim-i Vekayi'de yer alan Tırnova cadılarıdır. Bu olay literatürde 19. yüzyılda süreli yayınlarda yer alan tek olay olarak tanımlanmıștır (Kırgi, 2018; Aycibin, 2008, 55-70; Yaltırak, 2013, 187-232).

Bu çalışmanın amacı, 1872 ve 1874 yıllarında süreli yayınlarda "cadı vakası" şeklinde yer alan iki olay etrafında dönem mizah dergilerinin "cadı" olgusuna nasıl yaklaştıklarını ve bu olguyla ilgili nasıl bir söylem oluşturduklarını tespit etmektir. $\mathrm{Bu}$ amaç doğrultusunda literatürde yer alan olayların temel özellikleri saptanarak 1872 ve 1874 yıllarında süreli yayınlarda yer alan olaylar arasındaki benzerlik ve farklılıklar ortaya konulmaya çalışılmıştır. Çalışmada içerik çözümlemesi yöntemi kullanılmıştır. Çalışma, "cadı vakası" haberlerinin yayımlandığı 1872 ve 1874 yıllarında yayın hayatını sürdüren Diyojen, Hayal, Latife ve Tiyatro mizah dergileri üzerinden ele alınmıştır. Mizah dergilerinin çalışma kapsamında veri alanı olarak seçilmesinin altında yatan etken ise toplumsal gerçekliğin mizah ile olan güçlü ilişkisidir. Gündelik hayatın gerçekliği bireyin "şimdiliği" ve "buradalı̆̆ı" etrafında düzenlenmiştir (Berger \& Luckmann, 2008, 35). Mizah da geçerliliğini tıpkı gündelik hayat gibi mekan ve zaman üzerinden sağlar. $\mathrm{Bu}$ açıdan mizah 
dergileri bir olgunun toplumsal hayattaki karşllığını temsil gücüne sahiptir. Başka bir ifade ile toplumsal hayatta yer edinmiş inanç, söylem ve zihniyet mizah dergilerinin temel malzemesini oluşturmaktadır. Bu çalışmayı önemli kılan unsur ise 19. yüzyılda kayıtlara geçmiş tek "cadı vakası" olma özelliğine sahip Takvim-i Vekayi'de yayımlanmış "Tırnova cadıları" dışında literatürde yer almayan iki vakayı inceleme konusu edinmesidir.

\section{19. Yüzyıla Kadar Osmanlı Coğrafyasında “Cadı” Vakaları}

"Cadı" kavramı telaffuz edildiğinde akla ilk gelen isim şüphesiz Ebussuud Efendi'dir. 16. yüzyılda vermiş olduğu üç fetva doğaüstü varlıklara ilişkin tespit edilen ilk kayıtlardır. Bu konuda vermiş olduğu üç fetvanın ilkinde bu tarz olayların varlığını kabul eden Ebussuud Efendi, "cadı" olgusunun ortaya çıkmasında kişinin günahkar olmasını sebep göstermiş ancak olgunun gayrimüslimleri ilgilendirdiğini de belirtmiştir. Olgunun kabulünün yanı sıra bu fetvanın bir diğer özelliği ise "cadı" olarak adlandırılan varlığın fiziki tanımlamasıdır: “(...) a'zasına kan gelip bedenini humret ihâta etmiş(...)"(“Organları kanlanmış, bedenini kızıllık sarmış" Bkz. Düzdağ, 2012, 263-264). İkinci fetvayı varlı̆ı̆n eylemleri etrafında ele almak mümkündür. Selanik'e bağlı bir köyde söz konusu varlığın köy sakinlerinin kapısında belirerek bir yerlere gitme daveti sonucu davet edilen şahsın ertesi gün ölü bulunması eylemlerin ana çatısını oluşturmaktadır. Üçüncü fetva ise varlığın nasıl yok edileceğine ışık tutar; ilk çare kalbe bir kazık saplamaktır. Bu yeterli olmaz ise başı kesilmelidir. Şayet bu da yeterli olmaz ise ceset yakılmalıdır (Düzdağ, 2012, 264-265).

17. yüzyılda Edirne'de yaşanan iki vaka bu tarz olaylar karşısında merkezin tutumunu göstermesi açısından önemlidir. Edirne'nin Maraş köyünde Bıyıklı Ali isminde bir şahsın mezarında "ervah-ı habise" (kötü ruhlar) alametlerinin görülmesi köy halkını korkutmuş ve durumun çözümü için kadıya başvurmuşlardır. Edirne 
kadısı, Ebussuud Efendi'nin fetvalarından haberi olduğunu ancak bu fetvaların bir kaydını bulamadığını belirterek merkezden yardım istemiştir. Kadıya gönderilen mesaj "ehval bilür naib" atanarak tayin edilecek çavuş marifetiyle şikayet konusu alametlerin tespit edilmesidir ki bu alametler de cesedin bozulup bozulmadığı ile kızıllaşmanın olup olmadığıdır (Köhbach, 1979, 84-85). Bıyıklı Ali vakasında neler yaşandığına ilişkin bir bilgi bulunmamaktadır. İkinci olay ise Edirne'nin Elhac Sarraf mahallesinde meydana gelmiştir. Üç ay önce ölmüss Cennet ismindeki bir kadının mezarında cadı alametleri görülmesi üzerine dört kadının şahitliğinde mezar açılmış ve cesedin bozulmadığı, vücudun renginin kızıllaşttğı tespit edilmiştir. Bu durum karşısında merkez, halkın korkudan kurtarılması için gerekenin yapılmasını emretmiştir (Köhbach, 1979, 85). Bu iki vakada merkezin benzer olaylara ilişkin öncelikle "tespit" talebinde bulunması ve sonrasında ise net bir çözüm yolu göstermek yerine gerekenin yapılmasını emretmesi Aycibin'in ifade ettiği gibi bir "acemiliğe" (Aycibin, 2008, 61) delalet etmesinin yanı sıra doğaüstü olayların/varlığın resmi olarak kabul edilmesinin de bir göstergesi sayılabilir. En azından cadı vakalarında cadılık alametleri noktasında merkezin bir şablonu olduğunu da ileri sürmek yanlış olmaz.

18. yüzyılda yaşanan bir başka olay ise taşrada yöneticilerin sorunun çözümü noktasında inisiyatif kullanabildiklerini göstermektedir. Terkos'un Yeniköy mezarlığında 1743 yılında yaşanan cadı vakasında Terkos naibi cadıyı doğrudan yaktırmıştır (Aycibin, 2008, 61; Ayrıca bkz. Doğan, 2013, 232).

Osmanlı coğrafyasında yaşanmış en meşhur cadı vakalarından birisi kuşkusuz Tırnova cadılarıdır. Devletin resmi gazetesi Takvim-i Vekayi'nin 21 Cemaziyelevvel 1249 tarihli sayısında Tırnova naibi Ahmet Şükrü Efendi'nin ilâmı olduğu belirtilen yazı "cadı" olgusunun tüm yönlerini barındırmaktadır. Tetikoğlu Ali Alemdar ve Abdi Alemdar ismindeki iki eski yeniçeri cadıya dönüşmüş, gözle görülmeyen bir formda evlerde bulunan erzağı birbirine karıștırıp 
yastık yorgan gibi eşyaların yerlerini değiştirerek ve yüksek bir yerden insanların üzerine taş, toprak ile tabak çanak atarak ahaliyi korkutmuşlardır (Takvim-i Vekayi, 6 Ekim 1833) ${ }^{1}$. Hortlayan bu iki eski yeniçeriden kurtulmak için İslimiye kazasından Nikola ile 800 kuruşa anlaşılmıştır. Nikola, üzeri resimli bir tahtayı parmağında hareket ettirerek cadıların bulunduğu mezarı tespit etmiş ve mezar açıldığında iki cadının vücudunun sağlıklarındaki vücutlarının iki katı olduğu, saç ve tırnaklarının uzamış olduğu ve de gözlerini kan bürüyerek korkutucu bir hale geldikleri "cemm-i gafîr" (büyük insan kalabalığı) tarafından görülmüştür. İki cadının önce kalpleri kızgın suda haşlanır ancak etki etmediği görülünce cesetler yakılır (Takvimi Vekayi, 6 Ekim 1833).

Tirnova olayının temel unsurları 19. yüzyıla kadar gözlemlenen diğer cadı vakaları ile benzerlikler taşımaktadır. Öncelikle hortlayan bu iki eski yeniçeri hayatta iken mal gasbı, ırza geçme ve insan öldürme gibi kötülükler yapmışlardır. Yani Ebussuud Efendi fetvalarına göre günahkârdırlar. Bununla birlikte kaldırılmış yeniçeri ocağının üyesi olmaları da günahkârlıklarını pekiștirmektedir ki Ortaylı, Tırnova olayını yeniçeri ocağına karşı beslenen kinin ve devletin anti-yeniçeri ideolojisinin bir tasavvuru olarak değerlendirmiștir (Ortaylı, 2001, 38). Cadılardan kurtulma yolları açısından kalbin kaynar suda haşlanması yöntemi ilk defa karşımıza çıkmaktadır. Cadıların temel özelliklerine ilişkin göz ile görülememe/görünmez olma durumu önceki olaylarda üzerinde durulmamış bir unsurdur. Yaşayanlara karşı gerçekleştirdikleri eylemler esnasında cadıların görünmez olması ancak alametlerin tespiti sürecinde görülebilir bir formda olmaları bu vakada karşılaşılan bir ilktir. Bu olayda yer alan bir başka ilk ise "cadıcı"

\footnotetext{
1 Tırnova halkının yaşadı̆̆ı korkuyu anlatmak için Ahmet Şükrü Efendi, dört beş aylık bir bebeğin annesinin yatağından oda kapısına kadar çekildiğinden özellikle bahsetmektedir: “(...) hatta dört beş aylık henüz bi-nefsihi meşy ü harekete adimü'l-iktidar olan bir nefer sagiri validesi firaşından oda kapusuna değin keşide (...)"(Takvim-i Vekayi, 21 Cemaziyelevvel 1249/6 Ekim 1833, 3 ).
} 
kavramıdır. Cadılık alametlerini ve cadılar ile mücadele etme yöntemlerini bilen "profesyonel" cadıcıların, cadı ile mücadelede önemli bir unsur olduğu bu olayda gözlemlenmektedir. Ursinus'un çalışması da göz önüne alındığında özellikle 19. yüzyılda "cadıcı" ya da "cadı üstadı" unvanları ile bir hizmet sektörünün varlığından bahsetmek mümkün gözükmektedir. ${ }^{2}$ "Cadıcı" ve "cadı üstadı" unvanlarına sahip kişilerin varlığı ve bu kişilerden hizmet satın alınmasının altında yatan unsur Aycibin'e göre cadı vakalarının yaşandığı bölgelerde iç göçün önüne geçmek ve bu yolla vergi sisteminin aksamasını engellemektir (Aycibin, 2008, 65-66). Bu çıkarım doğrultusunda devletin cadıcıların sunmuş oldukları hizmeti halkta meydana gelen korku ve dehşeti bertaraf eden bir plasebo etkisi yarattığı için kullanmayı tercih ettiği ileri sürülebilir. Kayıtlara geçmiş cadı vakalarında halkın öncelikle bölgeyi terk etme isteğinin dile getirildiği dikkate alınırsa devletin bu tercihi daha anlamlı hale gelmektedir.

Farklı zaman dilimlerinde aktarılmış olan olaylar incelendiğinde 19. yüzyılın ilk yarısı itibari ile "cadı" olgusuna ilişkin genel bir çerçeve ya da şablon oluşturmak mümkündür. Bu çerçeve; alametler, sebep, eylemler ve mücadele yöntemleri olmak üzere dört başlıktan oluşmaktadır. Cadı vakalarında ölünün cadı olduğuna dair alametler; vücuda kan gelmesi, bedenin kızıllaşması ve cesedin bozulmaması şeklinde tanımlanabilir. Kişinin cadıya dönüşmesindeki temel etken kişinin sağlı̆̆ında yaptığı kötülüklerdir. Bu noktada cinsiyetin bir önemi yoktur. Cadıların sergiledikleri eylemler içinde Ebussuud Efendi'nin ikinci fetvasına konu olan olay dışında ölüme yol açan bir eylem kayıtlarda yer almamakla birlikte yaşayanları

2 Makedonya Arşivi'nde yer alan masarif defterlerindeki üç kayita göre 1836-1839 yılları arasında cadıcılara sırasıyla 100 1/2 ve 252 kuruş ödeme yapılırken üç defa hizmet alınan cadı üstatlarına ise toplam 980 kuruş ödeme yapılmıştır (Bkz. Ursinus, 1992, 359-360). "Cadıcılık" olgusuna Ursinus'un çalışması kapsamında şerh koyan Doğan, 3 yıllık masarif defteri kayıtları ile böyle bir olgudan bahsedilemeyeceğini ya da peşin hüküm verilemeyeceğini belirtir (Bkz. Doğan,2013, 233). 
rahatsız edici eylemler -taş, toprak atma ve eşyaların yerini değiştirme gibi- ya da gündelik hayatı sekteye uğratan eylemler temel eylem biçimlerini oluşturmaktadır. Mücadele yöntemleri ise kalbe kazık saplama, başın kesilmesi, kalbin kaynar suya atılması ve nihai olarak bedenin yakılması şeklinde sıralanabilir.

\section{19. Yüzyıl Türkçe Mizah Basınında "Karaferye Cadıları" ve “Cadı" Olgusu}

Osmanlı'da 19. yüzyılda Takvim-i Vekayi'nin aktardığı Tırnova cadılarının dışında “cadı” vakasına Teodor Kasab’ın sahibi olduğu Diyojen dergisinde rastlanmaktadır. Derginin mektup formunda yayımladı̆̆ı yazıda imza ve tarih bulunmamaktadır:

Karaferyeden Mektub

Ne de acaib vakitlere kaldık!

Malûmunuz olmak gerektir ki buralar (cadı) membaı olmakla mâruftur.

Tanzimat tarihinden beri bu belâdan kurtulduk zannında bulunurken bundan biraz evvel yine zuhûr etmesin mi?

Buralarda köy kethüdalığıyla geçinir bir adam var idi. Adına Bektaş Dayı derlerdi. Baba paşa yolunda gayet mütegallib gayet şirret bir adam olduğundan dünya elinden bi-zar olmuş idi. Akıbet-i ahirete teşrif etti.

Meğer herif çok yaşamışsa da dünyasına doymamış nasılsa çaresini bulur (cadı) olur. Pancar gibi kan kırmızı bir suret kaplan gibi iliștiği yeri koparır bir tırnak peyda eder. Bir hışm bir şiddetle memlekete uğrar.

Ama bilseniz ne de mashara bir (cadı) olur! Ahşam ziy-hayata musallat olan ervah-ı habise yanında halt etsin! Her gece evlere girer. Seccadeyi abdest-haneye serer. Abdest-hane na'leynlerini sofranın üzerine kor. Mangalı baş aşağı devirir mangal kapağını baş yukarı çevirir. Ahurdaki hayvanları evin üst katına çıkarır. Üst katındaki insanları ahura indirir. Çekmeceleri açar. Paraları mücevherleri bahçeye döker. Bahçeyi kazar. Eline geçen taşları süprüntüleri çekmecelere doldurur. Tavanı eğriltir. Nerdübânı düzeltir. Evdeki gelini babasının damadı kayınvalidesinin koynuna kor. Sevmediği istemediği ne kadar adam hayvan filan varsa bir dakika bir yerde oturtmaz bir dakika uyku uyutmaz. 
Kimini kolundan tutar pencereden aşağı atar. Mahallede ne kadar köpek bulabilirse arkasına düșer havlatır. Kimine sabaha kadar taş taşıtır kimine lâ-yenkati ortalık süpürtür. Sevdiği istediği adamlar hayvanlar filanları ise minare tepesi yar ağzı cambaz ipi gibi durulamayacak bir yere çlkarır bırakır. Herkesten para çarpar her sofradan ekmek kapar.

Akıbet-i iş bir dereceye gelir ki herkes canından hayatından bizar olur. Cenab-ı Hakktan bu belanın def'ini niyaza başlarlar. Memleketin en gayretlileri bununla da iktifa etmezler. Nüsha yazarlar (cadı) ile bi'n-nefes uğraşmaya kalkışırlar. Bu teşebbüslerin her biri muvaffakatının adâdına bir dereceye kadar hizmet eder. Fakat bir te'sir-i kati hasıl edemez.

Akıbet halkın rahatını iltizam eden eshab-ı hamiyyetten bir zât davat-ı hayriyye için icabet-gâh olmakla meşhur olan bir mübarek makama gider. İbâdullah üzerinden musibetin def $i$ için kemal-i hulus u sadakatle niyaz-ı merhamet eyler

Be-tevfikullah ki duası makbul olur. "cadı" yine sûrah mezarına çekilir. Cenab-ı Hakka yüz bin şükürler olsun şimdi herkes evinde rahatça işiyle meşgul olmaktadır.

Cumartesi günü yakarlar $\mathrm{ml}$ imiş mahkemeden giderler üzerinde ilâmı okurlarmış ne yaparlarmış bilmem. Şimdi anı yapıp da bütün bütün elinden kurtarmaya çalışılır (Diyojen, 17 Ağustos 1872, 1-2).

Diyojen dergisi tarafından aktarılan Karaferye ${ }^{3}$ vakası "cadı şablonu"nun dört başlığı üzerinden değerlendirildiğinde öncelikle olayın başkarakteri olan Bektaş Dayı'nın sağlında zorba olması ve insanlara eziyet etmekten imtina etmemesi "hortlama sebebi" olan "günahkâr olma" kıstasına uymaktadır. Cadının sergilediği eylemlerin yaşayanların gündelik hayatını sekteye uğratan ya da günlük işlerin sürekliliğini kesintiye uğratan eylemler olması ve de bu eylemlerin merkezinde sadece insanların değil hayvanların da yer alması eylemlerin "zorbalık" kavramı ile açıklanabilmesini mümkün kılmaktadır ki bu eylemlerin şablona uygunluğunu gösterir. Alametler noktasında da kanlanmış organlar ve uzamış tırnaklar ile cesette meydana gelen temel değişimler şablona uyum

3 Karaferye, Selanik'in batısında, Selanik-Manastır demiryolu üzerinde, bugünkü adı Béroia (Véria) olan şehirdir. 15. yüzyılda Osmanlı hakimiyetine geçmiştir (Bkz. Kiel \& Gara, 2001, 24/391-394). 
göstermektedir. Mücadele yöntemleri hususunda metinde aktarılan "dua" 4 etkeni ilk kez karşılaşılan bir usul olmasının yanı sıra kısmi bir çözüm sunduğu için nihai çözümün cesedin yakılmasıyla elde edilmesi de "cadı şablonu"na uygundur. Bu olay ile ilk kez karşılaşılan olgu ise cadının yakılması için seçilen günün cumartesi günü olmasidır.

Karaferye'de yaşanan bu olayın en ilgi çeken kısmı ise Tırnova olayı ile olan benzerliğidir. Öncelikle mektubun girizgahı oldukça tanıdıktır; “(...) Malumunuz olmak gerektir ki buralar (cadı) membaı olmakla mâruftur.(...)" cümlesi Ahmet Şükrü Efendi'nin ilamının girizgahı olan "(...) Rumeli toprağında örneğiyle görülmüş olduğu üzere Tırnova şehrinde cadı ortaya çıkmış(...)" ("Rumeli arzında mesbuk bi'l-misl olduğu üzere medine-i Tırnova'da cadu zuhur" Bkz. Takvim-i Vekayi, 6 Ekim 1833, 3) cümlesini anımsatmaktadır. Bunun yanı sıra “(...) Tanzimat tarihinden beri bu beladan kurtulduk zannında bulunurken (...)" ibaresi ile de Tırnova olayına atıf yapıldığı aşikârdır. Bu benzerliklerle birlikte metnin kaynağının belirsizliği ve

4 "Cadı ile mücadele noktasında "nefes"ine başvurulan kişileri Abdülaziz Bey "ocaklı" olarak tarif eder: [hortlakların] “(...) saldırı ve kötülüklerinden korunmak için ocaklı tabir edilen bir takım okuyuculara da başvurulur, onların aldığı tedbirlerle kurtulmak mümkün olurmuş (...)” (Bkz. Abdülaziz Bey, 1995, 374). "Dua" olgusunun halk söylencelerine dahil edilmesinde yerel hikayelerin kültürel geçişliliği de göz ardı edilmemelidir. Müslüman ve Hıristiyan toplulukların bir arada yaşadığı Selanik bu anlamda önemli bir merkezdir: “(...)Yerel bir öyküye göre, bir bașpiskopos İslamı benimsemiş ve önde gelen bir molla olmuştu. Hala Hıristiyan iken, bir öfke anında, cemaatinden birini lanetlemişti: 'Toprak seni içine kabul etmesin!' Adam ölmüş ve üç yıl sonra bedeni mezardan çıkmış olarak bulunmuştu. Kuşkusuz ceset 'sanki dün gömülmüş gibi' bozulmamış bir haldeydi aforoz eden din adamının kendisi artık din değiştirmiş olmasına karşın, aforoz hükmü hala geçerliydi ve artık bir Müslüman olsa da, hükmü geri alabilecek olan kişi sadece oydu: 'Paşa'nın iznini alarak açılan mezarı düzeltti, yanı başına diz çökerek ellerini kaldırdı ve birkaç dakika dua etti. Anlatması çok tuhaf ama, ayağa henüz kalkmıştı ki, cesetteki etler kemiklerine kadar un ufak olup iskelet sanki hiç kirlenme nedir bilmemiş gibi çıplak ve tertemiz oldu' (...)(Bkz. Mazower, 2007, 98). 
metnin Takvim-i Vekayi gibi "saygın"5 olmayan bir mizah dergisinde yayımlanmış olması olayın gerçekliği hakkında soru işaretleri oluşturmaktadır. Bu soru işaretlerini çoğaltan bir başka unsur ise dönem gazete ve dergilerinde kurmaca dışı ya da iktibas edilen metinlerin altına gazete ve derginin ismini ekleyerek kendi yorumlarını kaleme almaları geleneğinin söz konusu metinde bir örneğinin bulunmaması ve Diyojen'in metni sadece "Ne de acaib vakitlere kaldık!" cümlesi ile okuyucuya sunmasıdır. Ayrıca dönem basınının da olaya dair herhangi bir yazı yayımlamaması da bu olayın gerçekliği hakkında soru işaretlerini arttırmaktadır.

19. yüzyılın ikinci yarısında Diyojen dergisi dışında ikinci bir “cadı" vakasına 1874 yılında Selanik gazetesi yer vermiştir. Dönemin gazeteleri Şark, Basiret ve Medeniyet, Selanik gazetesinde yer alan yazıyı bire bir iktibas etmiştir:

Karaferyeden ahyânen zuhur eylediği gibi bu aralıkta birkaç cadı zuhur eylemiş ve ahali-i memleketi rahatsız etmiş olduğunu oradan gelen mevsûku'l-kelim bazı zevat müttefikan ve tevâtüren beyan ediyorlar vâkıâ bizce böyle şeyler inanılır ahvalden değil ise de râvîlerin yalan söyler takımdan olmadığına ve an'anesiyle âsar-ı vücudunu delâil-i muknia ile beyan eylemekte olduklarına göre bazı mahallerde böyle şeylerin bazen zuhuruna kâil olmak taraf-ı galebe ediyor

Zira ahbâr-ı vâkıa-ı mütevâtireye nazaran bu habislerin orada etmediği habâset ve gitmediği hane kalmamış ve umum kasaba ahalisinin ve hattâ memurin-i hükümetin dahi vukuf-ı tam hâsıl etmiş oldukları anlaşıllyor.

Mukaddemleri böyle cadu zuhurunda hangi mezardan çıktığı tahkik ve muayene olup anlaşıldıktan sonra evvel mezarı küşad ile ihrak ediyorlarmış fakat şimdilerde evvel mezar sahibini çıkarıp incekara nehrine ilka eyliyorlarmış ve bu suretle defü ref' edilmedikçe ahali-i memleket rahatsızlıktan hâlas

\footnotetext{
5 Osmanlı'da Türkçe mizah dergilerinin yayımlanmaya başladığı 1870 yılından yasaklandığı 1877 yılına kadar resmi söylem iki tür gazete tanımlamıştır: ciddi gazete ve eğlence gazetesi. Diyojen, eğlence gazetesi sınıfı içerisinde yer almaktadır (1870-1877 yılları arası mizah dergilerinin kapsam ve işi hakkında resmi söylem için bkz. Demirkol, 2019, 23-59).
} 
olmuyormuş iş bu cadular cumartesi gecesi ve günü mezarından çlkmadığı cihetle tahkik ve muayene keyfiyyeti evvel gün veya gece icra olunurmuş ve cadu olan mezardan bir küçük delik hâsıl olup hangi mezardan cadunun çıktığı bununla ve sair âsariyle bilinirmiş bu mezar küşad olundukta cenazenin naaşı çürümedikten başka mosmor kesilmiş ve tüyleri ok gibi dikelmiş bir halde bulunup bir tarafına âlât-ı cârihadan bir şeyle dokunulsa şiddetle kan fişkırır imiş geceleri gittiği hanelere bu vücud gitmeyip rüzgar gibi bir șey gürültü eder ve taş toprak ve sair türlü şey getirip atar ve bazen ziyy-i kıyem şeyler dahi öteden beriden çalıp getirirmiş ve bazen köpek yavrusu gibi ses çıkarırmış ateşten korktuğundan mı neden ise ziyade ateş yanan yerlere gitmez ve kaçarmış attığı taşlar birine tesadüf etse de el ile konmuş gibi gayet hafif düştügü cihetle incitmezmiş.

Ve kendisine hitap olarak bir söz söylenirse bazen isga edip mesela felan şeyi getir dediklerinde az bir zaman içinde gidip bir taraftan istenilen şeyi bulup getirirmiş bazen dahi pisliğe müte'allik șeyler döküp rahatsız eylermiș velhasıl bu gibi akla baid ahval ve hareketin vuku' bulmakta ettiğini râvîler yemin ederek söylüyorlar (Şark, 21 Eylül 1874, 2; Basiret, 21 Eylül 1874, 2-3; Medeniyet, 21 Eylül 1874, 2-3).

Cadı vakalarının temel özellikleri açısından bu olay da diğerleri ile uyuşmaktadır. İkinci kez Karaferye'de ortaya çıkan cadılar alametler noktasında şablona uygunluk göstermektedir: kanlanmış organlar ve bozulmamış ceset. Eylemler noktasında metinde tanımlanmış eylemlerin gündelik hayatı sekteye uğratan eylemler olması cadı vakalarının temel özellikleri ile örtüşmektedir. Metinde boş kalan kısım ise sebep unsurudur ki mezarından "hortlayan" şahıs hakkında bir bilgiye yer verilmemiş olması bunun sebebidir. Mücadele yolları açısından bu olayda ilk kez farklı bir yöntem ile karşılaşılmaktadır. Metinde daha önce yakarak cadı ile mücadele edildiğinden bahisle yeni bir mücadele yöntemi olarak cadının nehire atılarak "def'ü ref"” (savuşturma, ortadan kaldırma) edildiği belirtilmiştir. Cadı vakalarına ilişkin bu olay özelinde karşılaşılan ilkler sadece bununla sınırlı değildir. Metinde ilk kez cadının mezarına ilişkin alametlere de yer verilmiştir. Mezarın üzerinde 
oluşan küçük delik cadının bulunduğu mezarı gösteren temel alamet olarak aktarılmıștır. Bu durumu bir anlamda cadı ile mücadele noktasında "profesyonel" hizmet sağlayan "cadıcı" olgusunun kayboluşu olarak tanımlamak mümkündür. Mezar üzerinde oluşan deliğin cadıya ilişkin temel işaret olarak kabul edilmiş olması gerek alametleri gerekse mücadele yöntemlerini bilen "cadıcı"ların hizmetlerine ihtiyacın kalmadığına delalet etmektedir. Bu olay etrafında ilginç bir olgu ise bölge halkının cadı ile iletişime geçmesidir. Metne göre cadı kendisine hitap edildiğinde bazen "kulak vermekte" ve kendisinden istenileni yapmaktadır.

Selanik gazetesinde yer alan bu yazıyı iktibas eden Basiret gazetesi olaya ilişkin hiçbir yorum kaleme almazken Medeniyet gazetesi: "Bu mesellü hayaletin muhakemesi Hayal gazetesinin himmet-i kalemiyyesine aid bir vazifedir" (Medeniyet, 21 Eylül 1874, 3) şeklinde bir ibare ile fikrini beyan etmiştir. Gazetenin olayı ciddiye almadığı aşikârken Hayal dergisine gönderme yapması ilginçtir. Bu durumu Teodor Kasab ile Mehmet Arif arasındaki "rekabet" ile açıklamak mümkündür (Rekabet için bkz. Demirkol, 2019/17, 265293). Ancak düşük ihtimal de olsa Medeniyet gazetesinin Teodor Kasab'ın Diyojen dergisinde yayımladığı 1872 Karaferye vakasına gönderme yaptığı da düşünülebilir. Şark gazetesinin olaya ilişkin tavrı da Medeniyet gazetesinin tavrıyla benzerlik göstermektedir:

Şark

Hatırda kaldığına göre vaktiyle bir cadu dahi Diyarbekir vilayetinde çıkıp Diyarbekir gazetesi o vakit yine böyle mufassalan yazmış idi. Fakat o cadu mangalda kahve pişirir ve başına Üsküdar yemenisi de sarar idi. Terakkiyat-ı zamane şimdi bu caduların dahi ayaklarında fotin ve başlarında kırmızı fes bulunmasın icab eder iken Selanik gazetesinin oralara dair malumat alıp bahs etmişse taaccüb olunsa sezâdır (Şark, 21 Eylül 1874, 2).

"Ciddi" gazete olarak tanımlanan Basiret, Şark ve Medeniyet, Selanik gazetesinde yer alan olay karşısında ortak bir tavır benimsemişler, olayı "gazetecilik" görevi çerçevesinde sadece aktarmak ile yetinmişlerdir. Dönemin mizah dergileri ise günlük 
gazetelere nispeten Karaferye cadısına daha fazla sayfalarında yer vermiştir.

Selanik gazetesinin aktardı̆̆ı Karaferye'deki olaya en fazla değinen mizah dergisi Tiyatro dergisidir. 51. sayısında dergi, Selanik gazetesinin haber metnini ele alır:

Tiril tiril titriyorum! Korkuyorum.... Ödüm patliyor!... efendim korkulmayacak şey mi? Karaferyede cadı çıkmış cadı!.. şimdi nereye kaçmalı?.. ya buraya gelirse!.. Selanik buraya ne kadar çok yer... Bir vapura binince iki günde gelir. Hem cadıya vapurla gelmeye ne hacet... Vapursuz da gelir. Çünkü cadı bu... Hem de ne cadı... Herkesi korkutuyormuş. Evlere toprak atıyormuş... sakın ha inanmamazlık etmeyiz! İşte ben Şark da gördüm. O da Selanik gazetesinde görmüş. Şark yalan söylemez a. Selanik gazetesi ise hiçbir vakit yalan söylemez. Elbette cadı çıkmış ki söylüyor. Hem Selanik gazetesine haber verenlerde yemin ediyorlarmıș! Muhabirlerde zaten sözlerine inanılır adammış... Selanik gazetesi de birden bire inanmak iste[me]miş an'anesiyle âsar-ı vücudunu delâil-i muknia ile beyan etmişlerde Selanik gazetesi ondan sonra bazı mahallerde böyle şeylerin bazen zuhuruna kâil olmuş...

Öyle ya! İște bazen zuhur ediyor. Vâkıa benim hatrımda yok ama Şark'ın hatırında kalmış: vaktiyle bir cadı da Diyarbekir vilayetinde de çıkmış imiş...

Böyle dallı budaklı yalan olmaz a. Elbette sahihtir. Evvelleri de ara sıra karaferyede yine zuhur etmiş imiş. Hatta bu cadının mezarını açarlarmış cadıyı evvelleri yakarlarmış sonraları da incekara nehrine atarlarmış...

Selanik gazetesi bu cadı hakkında birçok mâlûmat-ı müfide veriyor. Diyor ki cadılar cumartesi gecesi ve günü mezarından çıkamazmış da işte o gün tahkik ve muayene olunurmuş ve cadı olan mezardan bir küçük delik hasıl olurmuş da cadı olduğu bu delikten bilinirmiş. Daha bazı âsarı da varmış... aferin Selanik gazetesi bakınız ne kadar çok mâlûmat veriyor!.. işte gazete böyle olmalı!..

Şimdi doğru söylemek lazım gelirse Selanik gazetesi vazifesini ifâ etmiş. İyice tahkik eylemiş. Cadının ahvalini iyice anlamış ve halka bildirmiş. Selanik gazetesinin tahkikatına göre cadının mezarını açmışlar. Cenazenin naaşı cürümemiş imiş. Bundan 
başka mosmor kesilmiş imiş. Tüyleri de ok gibi dikelmiş imiş. Fakat bereket versin ki geceleri gittiği hanelere bu vücutla gitmezmiş. Rüzgâr gibi bir şey gürültü edermiş ve taş ve toprak atarmış bir de bu cadı arada gittiği yerlere ziyy-i kıyem şeylerde götürürmüş... \{nasıl burası âla değil mi? ah bize gelse de böyle ziyy-i kıyem şeyler getirse!...\}

Hay koca cadı hay!.. Arada masharalık da edermiş. Köpek gibi bağırırmış. Hem de latîfe-perdaz şey!.. attığı taşlar birine tesadüf etse de el ile konmuş gibi gayet hafif düştüğü cihetle incitmezmiş!..

Sözde dinliyormuş. Bir şey söylense bazen isga edermiş. Mesela filan şeyi getir derlermiş de gider getirirmiş. Fakat bazen de pisliğe müteallik şeyler döküp rahatsız eylermiş. \{bana kalsa bunda cadının hakkı var. Herif herkesin hıdmetkârı değil a\} Vay!... şimdi bu cadı buraya da gelirse!.. Bana kalsa mademki Selanik gazetesi bunun aslını esasını biliyor elbette ilacını da bilir. Şimdi biz ona gidip bu cadı buraya gelmeden bir ilaç öğrenmeliyiz!... (Tiyatro, 23 Eylül 1874, 1-2).

Tiyatro dergisi olayın inandırıcılıktan uzak olduğuna ilişkin düşüncesini açıkça ortaya koyarken bu kanıya varmasında etkili olan unsurların başında haberin kaynağına dair Selanik gazetesinin ortaya koyduğu söylem gelmektedir. Haberin inandırıcı olmadığına ilişkin kanısının bir başka dayanağının cadıya ilişkin Selanik gazetesinin aktardığı eylemler olduğu Tiyatro dergisinin bu eylemlere yoğunlaşmasından anlaşılmaktadır ki cadının kıymetli eşyalar getirmesine dair bilgi karşısında "\{nasıl burası âla değil mi? ah bize gelse de böyle ziyy-i kıyem şeyler getirse!...\}" şeklinde bir ifade kaleme almış olması bunun somut delilidir. Derginin 52. sayısında Karaferye cadısına dair kaleme alınan yazının da ana eksenini bu eylemler oluşturmaktadır:

Ne dersiniz hala şu cadının korkusundan kurtulamadım? Adını işitince bir acayip hal oluyor. Gözlerim kararıor. Benzim sararıyor. Ödüm patlıyor. Sıtma tutmuş gibi dişlerim birbirine vurmaya başliyor.

Ne yapmalı bilmem ki?!... tutulmaz ki yakalayıp da haddini bildiresin!...

Ah cadı ah!... bir de bakarsın ki sokakta geziyor. Tutayım diye yanına sokulacak olsan bir tokat vurunca adamın otuz iki dişini 
birden söker!...

Ah efendim! Bu cadı bir kıyafette dursa insan o kıyafeti beller de onu görünce bir yere saklanır. Bu öyle değil ki! Karnaval \{mashara\} ları gibi günde bin șekle hulûl ediyor. Mesela şimdi bakarsın ki bir gazete müvezzi kıyafetine girmiş. Şark. Basiret. Ruzname. Hülasa. Mecmua diye bağırıyor. Aman demeye kalmaz birde bakarsın ki bir beygirci şekline girmiş. Beygirlerini katara bağlamış çoluğu çocuğu çiğneterek beygirlerini koşturup gidiyor. "bakındı cadıya" diye taaccüb etmeye gelmez birde bakarsın ki gözüne gözlük takmış eline baston almış. Başına şapka giymiş bir âlâ paytonda yan gelmiş oturmuş. Fransızca söylemeye başlamış. Olmuş bir sivilize... ah ah!.. bu cadının ettiği fenalık bir değil beş değil on değil... yüz bin değil... Mesela sivilize klyafetine girince istediği yere gider. Hiç kimsenin giremediği deliklere girer. Elmas çalar. Mücevher çalar. Geceleyin bir takım evlere girer çocukları korkutur. Maymun gibi ağaçlara çıkar. Kedi gibi adamın elini tırmalar. Mesela eline bir tezkere verir de dersen ki "haydi felan yere gitte şu tezkereyi felan adama ver. Bana on kuruş getir." Peki efendim der. İstediğinizden ziyadesini getiririm diye böbürlenir. Sen de memnun olursun. Birde bakarsın ki bir ay ortalıktan kaybolur. Sonra gelir. Sana üç buçuk kuruş verir. "a canım hani bunun üst tarafı?" deyince bin dereden su getirir. ne yaparsın? Elden ne gelir?

İşte bu sivilize kıyafetine girer adamı böyle aldatır. Tutar bir mühendis klyafetine hulûl eder Almanca söylemeye başlar... (Tiyatro, 26 Eylül 1874, 2-3).

Tiyatro dergisi tarafından parodiye dönüştürülmüş cadının eylemleri aynı sayıda telgraf formu ile tekrarlanmıştır:

\section{Eylül}

Cadı bu gece beş eve vizite verdi. Bir eve bir elmas yüzük getirdi. Kusûr evlere toz toprak attı cadı biraz nâ-mizaçdır.

11 Eylül

Cadı gelecek cumartesi günü yakılacakmış bu gece iki eve girdi ikisini de süprüntü etti.

12 Eylül

Cadı bu gece kendisine her ne söylendiyse cevap verdi. İstanbul gazetecilerinin hepsine selamı var. Sihhati yolundadır.

13 Eylül 


\section{Gökhan DEMIRKOL}

Cadının karaferye nehrine atılmasına karar verildi. Cadı bu gece on dokuz eve gitti. Ne kimsenin istediğini getirdi ne de söylenen sözlere cevap verdi. Biraz nevâzili varsa da sıhhati yolundadır.

Tiyatro tarafından karaferyeye çekilen telgraf 14 Eylül

Cadıyı bu cumartesi behemehâl nehre atınız. Yoksa başınıza bir bela getirir (Tiyatro, 26 Eylül 1874, 4).

Selanik gazetesinin aktardığı olayın gerçek dışı olduğuna ilişkin Tiyatro dergisinin hiçbir şüphesi bulunmamaktadır. Bu sebeple de derginin 51 ve 52. sayısında yer alan yazılar genel "cadı" kavramından ziyade olay odaklıdır. "Cadı" kavramının toplumsal hayattaki karşılığına dair ipuçlarını ise Hayal dergisinde bulmak mümkündür. Karaferye olayından yaklaşık bir ay önce yayımlanmış muhaverede Karagöz ile Hacivad Karamürsel'deki ${ }^{6}$ bir cadı vakası hakkında konuşmaktadır:

- Karagöz haberin var mı? Karamürselde cadı çıkmış.

- Vay anasını be! Hacivad gördün mü başımıza geleni?

- Ne var?

- Ne olacak ben cadıdan korkarım. Acaba Karamürsele nereden gelmiş?

- Bilmem. Lakin her gece evlere girip alt üst ediyormuş. Taş atıyormuş. Kapları bafar birbirine katıyormuş. Mum yakıyormuş. Bazen söndürüyormuş.

- Bak belaya!

- Ne o benzin attı.

- Nasil atmaz. Yarın buraya da gelirse?

- Yok canım buraya gelmez hem zati Karamürselli imiş.

- İyi ya a babam Karamürselle İstanbulun arası iğne boyu kadar bir yer hele şimdi şimendifer de var

- Korkma karagöz İzmite yazmışlar İzmitten de buraya bildirmişler yakacaklarmış.

- Aman Hacivad yalan olmasın belki seni aldatmışlardır.

- Yok a kuzum yalan değil oradan gelen köylüler söyledi. Hatta

${ }^{6}$ Karamürsel'de yaşanmıș bir olay hakkında dönem gazetelerinde herhangi bir verinin bulunmaması "Karaferye" ifadesinin sehven "Karamürsel" şeklinde yazıldığını akla getirmektedir. Ancak Karaferye olayına dair Selanik gazetesinin hangi tarihte yayın yaptığı gazetenin nüshalarının arşivlerde bulunmaması sebebi ile mümkün olmadığından bu açıklamada soru işaretleri barındırmaktadır. 
ekserisi köyü bırakıp öteye beriye savuşmuşlar.

- İşte fenası o ya! Orada kimseyi bulamayınca soluğu burada alır. Yine zihnim karıștı sende musibet dellali misin nesin. Nerede korkunç bir havadis olursa hemen haber alırsın.

- Canım Karagöz bunda korkacak bir şey yok o kadar telaş etme. Onun kimseye bir zararı dokunmaz.

- Evet bende biliyorum kimseyi öldürmez. Ama öldürmeden beter eder artık ha bu eve geldi ha öteki eve gelecek diye herkeste bir yürek çarpıntısı kimsede rahat huzur yok bu iyi mi ya?

- İște karar vermișler yakacaklarmıș.

- Anladık a babam yakacaklarına kurşunla ursalar olmaz mı?

- Karagöz sen çıldırdın mı? Hiç cadı göze görünür mü?

- Ey ya mademki göze görünmez nasıl yakacaklar?

- Onu yakmanın usulünü bilenler vardır mezarını açarlar kireçle yakarlar.

- Vay! Demek ki bu öldükten sonra cadı olmuş?

- Öyle ya cadı öldükten sonra olur

- Bak ben bunu bilmezdim benim bildiğim cadıların hepsi sağ lakin bereket versin öyle ortalığı alt üst edecek kadar kuvvetleri yok yoksa onlarda bir orduyu birbirine katarlar ben ise bunu onlarm bir kuvvetlisi zan ettim de maazallah halimiz ne olur diye korkuyordum.

- Aman Karagöz ben cadının sağını şimdiye kadar kimseden duymadım. Cadının sağı nasıl olur.

- Hacivad tuhafsın ihtiyarladın da çocuk gibi oldun bir şeyi çabucak unutuyorsun işte biri de senin başında benim kayınvalide ile senin bacı kımıldanmaya kudretleri olmadığ halde ortalığı birbirine katıyorlar ya kuvvetleri de yerinde olsa da istedikleri yere gitseler....

- Hay Allah cezanı versin! Benim dediğim öyle cadı değil.

- Ben de cadının öldürülmesine müsaade varmıș diye az daha bu gece kayınvalidenin boğazını sıkacaktım (Hayal, 19 Ağustos 1874, 2-3)

Hacivad ile Karagöz arasında gerçekleşen bu muhaverede "cadı"nın temel eylemleri önceki olaylarda aktarlan eylemler ile uyuşmaktadır. Gündelik hayatı sekteye uğratan eylem biçimleri şeklindeki davranışların genel olarak halk arasında huzursuzluk ve korku yaratması burada da gözlemlenmektedir. "Cadı”ya ilişkin temel 
eylem biçimlerinin yanı sıra "görünmez" olma durumu da başat unsur olarak karşımıza çıkmaktadır. Bu yazıyı önemli kılan unsur ise "cadı" kavramının yaygın toplumsal tanımlamasını vermesidir. Karagöz'ün özellikle “(...) benim kayınvalide ile senin bacı kımıldanmaya kudretleri olmadığı halde ortalığı birbirine katıyorlar ya (...)" ifadesi kavramın toplumsal hayatta daha somut olarak "bedhuy ve bed-lika kocakarı, acûze" anlamları üzerinden işlerlik kazandığını göstermektedir.

Dolaylı olsa da Karaferye olayı üzerinden Türkçe mizah dergilerinin gündelik hayattaki olay, durum ve ilişkileri açıklama noktasında "cadı" olgusuna başvurdukları görülmektedir. Selanik gazetesinin aktardığı Karaferye olayı karşısında sessiz kalan Latife dergisi, "cadı" olgusunun temel niteliği olan "hortlama" ya da "ölümden sonra hayata dönme" özelliğini Hülâsatü'l Efkâr gazetesinin kapatma cezası alması ve sonra tekrar yayımlanması ${ }^{7}$ süreci için kullanmıștır. Latife dergisinin 9. sayısında telgraf formatında yayımlanan yazıda "hülâsatü'l efkarın mezar taşında biraz hareket ve canlanma alameti müşahade olunuyor" (Latife, 21 Eylül 1874, 4) ifadesi kullanılmıştır. Selanik gazetesinin Karaferye haberinin yayımlanması üzerine Latife dergisi Hülâsatü'l Efkâr'ín durumu ile “cadı" olgusunu ilişkilendirir:

Karaferyede cadı çıkmış olduğunu Selanik gazetesinde meşhud nazar-ı dehşet u havfımız olmuştur. İstanbulda da cadılar çıkmaya başladı. Hatta geçen nüshamızdaki telgraflar sırasında Hülâsatü'l Efkârın mezarında canlanmak hareket ve emareleri müşahid olunur demiş idik. Sonra tahkik ettik ki o mezardan bir cadı çıkmış veya çıkmaya hazırlanmış imiş!! (Latife, 24 Eylül 1874, 4).

7 Antuvan'ın sahibi olduğu gazete 23 Haziran 1874 tarihli nüshasında iki ay kapatma cezası almış ancak bir ay sonra 21 Temmuz 1874 tarihinde yayımlanmasına izin verilmiştir (Bkz. Hülâsatü'l Efkâr, 21 Temmuz 1874, 1). Hülâsatü'l Efkâr gazetesi 1874 yılının Aralık ayında da bir ay kapatma cezası almıştır (Bkz. Hayal, 16 Aralık 1874, 3). 
"Hortlama” unsurunu Hülâsatü'l Efkâr gazetesinin kapatma cezası alma ve tekrar yayımlanma sürecini tanımlamak için kullanan Latife dergisi, Mecmua-i Maarif gazetesi için de aynı unsuru tekrarlamıştır:

Gazeteler cadı çıktı filan diyerek bir takım gürültüler telaşlar göstermiş oldukları üzere biz hiçbir şey demeyerek netice-i hale muntazar olmuş idik: her hususta acele etmeyerek sabırlı bulunmak güzel bir şey olduğundan biz sabrımızdan bak ne bulduk! Ne keşfettik! (...) mecmuayı diyar-ı ademe gitti diyerek herkes fâtiha-han olmakta iken bir de ne görelim! Mecmua küçülerek ezilerek büzülerek arz-ı vücud etmesin mi?! (...) bunun üzerine düşündük taşındık! Herkesin çıktı çıktı diye bağrıștıkları cadı bu imiş! Vay koca cadı vay! (...) (Latife, 28 Eylül 1874, 1-2).

Hayal dergisi de Latife dergisi gibi yaşanan durumları "cadı" olgusu ile ilişkilendirerek açıklama eğilimindedir:

- Karagöz! Ne o benzin atmış?

- Aman sorma korkuyorum. İş fena.

- Hayr ola! Ne var ne oldu ki bu kadar korkmuşsun?

- Daha ne olacak hani ya karaferyede cadı çımamış idi?

- Ey çıkmış ise ne olmuş? Ondan sana ne?

- Buraya gelmiş.

- Kim söyledi?

- Kim söyledi var mı ya? Yaptığı șeyler meydanda duruyor.

- Canım iyi ya ne yapmış?

- Ne yapacak gelir gelmez sarkıntılığa başlamış hem de fenası şu ki gazetelerden başlamış.

- Karagöz delilik lazım değil kendini pabucu büyüğe okut.

- Hacivad ne söylüyorsun medeniyetle pazartesi günkü şarkı görmedin mi?

- Görmedim ne olmuş?

- Olmuşu olacağı meydanda medeniyeti kasmış kavurmuş biçareyi altı aylık çocuğa döndürmüş.

- Tuhafsın be Karagöz mukaddimesini okumadın mı? Medeniyet inhisar kabul etmediği için mekteb-i sanayinin taht inhisarında kalmamak istemiş lakin o hacimde bir gazeteyi tab` etmek için diğer matbaalarda dahi büyük makine olmadığından kendi 
makinesinin vüruduna kadar muvakkaten küçülmüş.

- Bunun tev'ilini buldun. Ya şarka ne diyeceksin bakalım? Hem öyle bir kuvvetli çarpmış ki altını üstüne getirmiş

- Vakıa orası da öyle lakin acaba o da karanlıkta bir yere su dökmüş olmasın? Kim bilir.

- Bileceği bilmeyeceği yok. Küçükten büyümüş gazeteler gördük ama büyükten küçülmüş ve böyle çarpılmış şimdiye kadar görmedik.

- Nasıl görmedik? Ne çabuk unuttun şark evvelleri ne idi Hülasatü'l Efkâr şimdiye kadar kaç kalıba girdi bilmiyor musun?

- Sen onlara bakma şark yaptığını söylediğini bilmez. Hülasayı dersen bizim Antuvanların elinde bulundukça aklına geleni yapar bir gün akşam çıkar ve artık bundan böyle akşamları çıkacağım der ertesi gün aklına eser sabahleyin şafakla sokağa firlar. Bazen kazaya uğrar bir müddet hiç görünmez onlar müstesnadır.

- Hay Allah senden razı olsun Hacivad ben ise cadı buraya gelmişte bunları o yapıyor zannıla bizim perdeden de korkuyordum meğerse hepsinin sebepleri varmış (Hayal, 7 Ekim 1874, 2).

Hayal dergisinin "cadı" olgusu ile ilişkilendirdiği ilk durum Medeniyet gazetesinin 22 Şaban 1291 (18 Eylül 1874) tarihli 19. sayısında matbaa değişikliği sebebi ile ebadını küçültüp mizanpajını 6 sütundan 4 sütuna düşürmesidir (Bkz. Görsel 1 ve 2). Bir zorunluluk karşısında gerçekleşmiş olan ebat değişikliğinin dönem mizah dergilerine konu olmasının altında yatan unsur ise gazetenin dönem gazetelerine kıyasla çok büyük ebatlarda yayımlanmasıdır ki bu durum Medeniyet gazetesi için "perde" benzetmesi (Bkz. Hayal, 16 Eylül 1874,2) yapılmasına sebep olmuştur. 


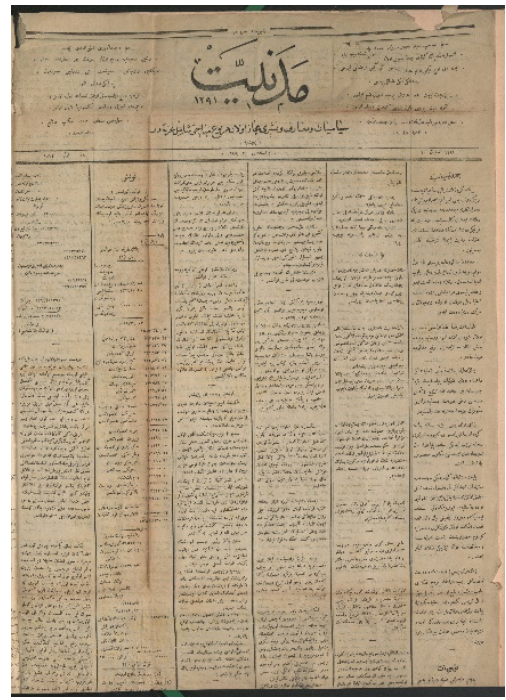

Görsel 1: Medeniyet, 20 Şaban 1291

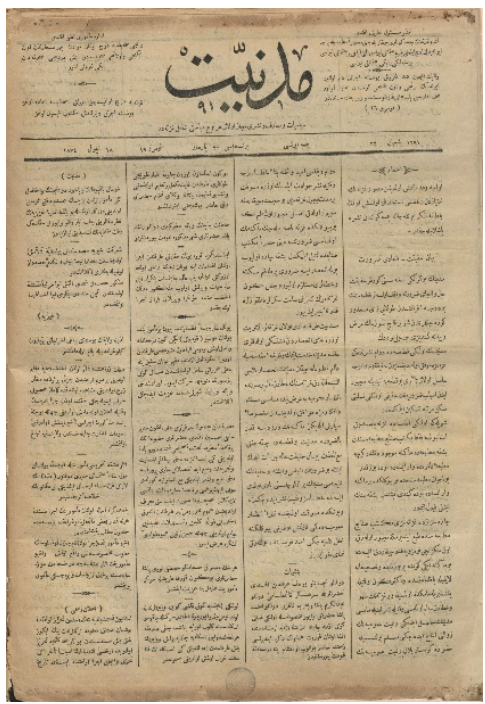

Görsel 2: Medeniyet, 22 Şaban 1291.

Gazetenin zorunluluktan kaynaklı durumu Hayal dergisi tarafından "(...) medeniyeti kasmış kavurmuş biçareyi altı aylık çocuğa döndürmüş" cümlesi ile "cadı" olgusuyla ilişkilendirilmiştir. Latife dergisi de Medeniyet gazetesinin bu durumunu farklı bir açıdan "cadı" olgusu ile ilişkilendirmektedir:

Medeniyet gazetesi küçülmüş! Ey ne çare evvelki nüshamızda da yazmış idik. Düşmez kalkmaz bir hacı yatmaz.

Fakat ihtarın alt tarafında "beyan-ı hakikat ve el-cadı zaruret" serlevhasıyla bir bend var. 0 serlevhadaki (el-cadı) ne demek? Acaba gazetelerin bağrıştıkları cadıyı tarif ve izah için cadının evveline bir harf-i tarif mi getirmiş? Eğer öyle ise (el-cadı zaruri) demeli idi o vakit mana-i şerif olurdu ki bu mananın tafsilini de tiyatrodan bekleriz. Çünkü o cadıyı çok sever biliriz (Latife, 5 Ekim 1874, 2).

Medeniyet gazetesi, ebatın küçülmesine dair okuyucularına bilgi verdiği yazıda "zorlama, mecbur etme" anlamına gelen "ilcâ" (للجاء) kelimesini sehven "el-cadı" (الجادى) șeklinde yazmıștır. "Cadı" 
kelimesinin önüne "el-“ öneki getirerek kelimeyi mârife ${ }^{8}$ yapmıştır. Dolaylı olarak Latife dergisi bu hatadan Medeniyet gazetesinin Karaferye cadısı hakkında bilgi sahibi olduğu imasını yapmaktadır.

Hayal dergisinin "cadı" olgusu ile Şark gazetesi arasında ilişki kurduğu durum ise bir baskı hatasına dayanmaktadır. Şark gazetesinin 23 Eylül 1290 (5 Ekim 1874) tarihli 251. sayısının ikinci sayfası ters basılmıștır" (Bkz. Görsel 3). "Ya Şarka ne diyeceksin bakalım? Hem öyle bir kuvvetli çarpmış ki altını üstüne getirmiş" cümlesi ile yaşanan durum Hayal dergisi tarafından "cadı" olgusuyla ilişkilendirilmiştir.

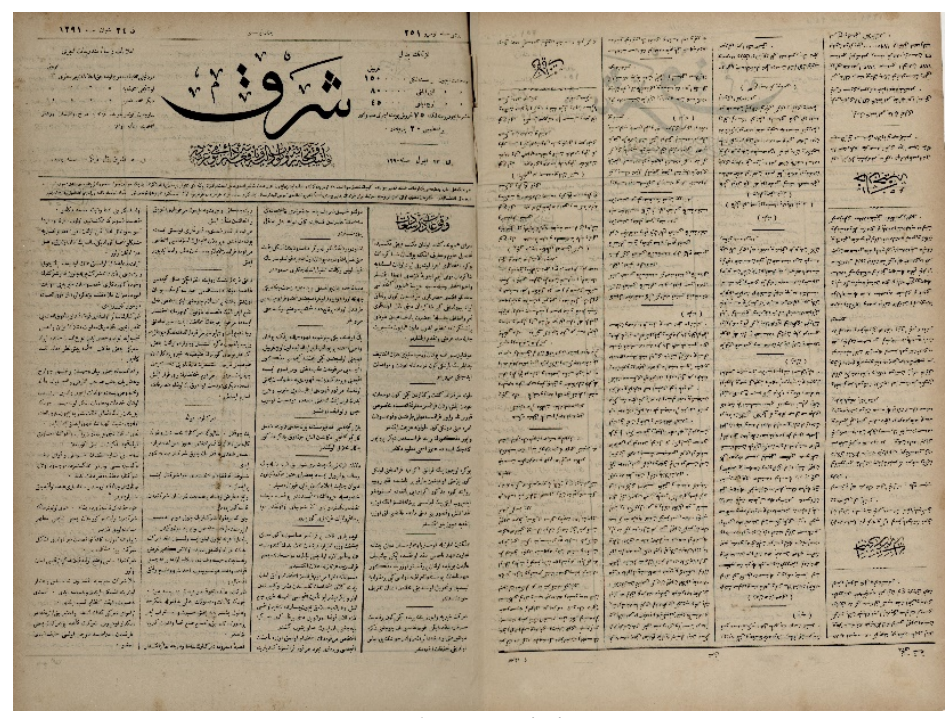

Görsel 3: Şark, 23 Eylül 1290, s.1-2.

8 Arapçada "mârife yapmak" bilinen hale getirmektir. Belirli bir kişi veya nesneden bahsedilirken kullanılır. İngilizcedeki "the" kullanımıyla benzerdir.

9 Şark gazetesi baskı hatası ile ilgili 252. sayısında bir açıklama yapar: "dünkü nüshamızın ikinci sahifesi destgâha konulduğu sırada sahifenin üstü altı fark olunmayarak ters vaz' edildiği gazetenin bir miktarı tab' olunduktan sonra görülüp düzeltildiğini (...)" (Bkz. Şark, 6 Ekim 1874, 2). 
Şark gazetesinin cadı tarafından "altını üstüne getirme" durumuna Hayal'in gösterdiği sebep ise oldukça ilginçtir: "(...) karanlıkta bir yere su dökmüş olmasın? (...)". Bu ifade "cadı" terimi altında tanımlanan olguların toplumsal hayatta yer edinmiş inanç söylemleri içerisinde "karanlık" ile bağdaştırıldığını ve nasıl bir eylem karşısında "sinirlenerek" harekete geçtiğine dair "itikat"ı da göstermektedir.

\section{Sonuç}

Osmanlı Devleti'nde kayıt altına alınan doğaüstü varlıklara ilişkin olaylar ele alındığında çatı kavram olarak "cadı" olgusu ile karşılaşılmaktadır. 19. yüzyıl sonundan itibaren bu kavram anlamsal bir genişleme göstererek batı tarzı "vampir" kavramı ile birlikte kullanılmaya başlanmıştır. İki kavram arasındaki anlamsal ilişkinin "cadı" ve "vampir" kavramlarının tanımladığı olgular arasındaki benzerliğin bir sonucu olduğu ileri sürülebilir. Anlamsal ilişkinin kurulması ya da kavramların birbirlerinin anlam havuzu içerisine dahil olmasında coğrafi unsurların önemi yadsınmamalıdır. Kayıt altına alınmış olayların özellikle Osmanlı Balkanlarında cereyan etmesi kültürel anlamda Osmanlı toplumunun batı tarzı "vampir" olgusunu benimseyerek gündelik dil başta olmak üzere inanç sistemine entegre etmesi sonucunu ortaya çıkarmıştır. Farklı kültürlere ait söylemlerin kaynaşarak yeni bir söylem etrafında şekillenmiş inanç yapıları oluşturması, bu yapıların ya da söylencenin toplumsal hayatta yer edinmesinin ve süreklilik göstermesinin de altında yatan etken kuşkusuz coğrafi unsurlardır.

19. yüzyıl, Osmanlı Devleti'nde bu tarz olayların halk söylencesi kalıplarının dışına çıktığı, yeni unsurların olay kalıplarına eklendiği ya da çıkarıldığı bir dönem olarak gözlemlenmektedir. Bu durumun ortaya çımasında en önemli etken ise şüphesiz "gazete" ya da periyodik yayın olgusunun hayat bulmasıdır. Takvim-i Vekayi gazetesinde yayımlanan Tırnova cadıları olayı söylence veya inanç 
olarak "cadı" olgusunun nasıl farklı bir kullanım alanı sağladığının iyi bir örneğidir. Bununla birlikte sözlü kültür unsurları olarak var olan söylem yapılarının yazılı kültüre geçişi ile birlikte tarihsel olarak geçirdiği değişimin takip edilmesini de kolaylaştırmıştır. Bu durum araştırmacılara toplumsal hayatın zihniyet haritasının çıkarılmasında önemli bir veri kaynağı sunmaktadır. 19. yüzyılda süreli yayınlara akseden üç olay (1833 Tirnova, 1872 Karaferye ve 1874 Karaferye olayları) "cadı" unsuruna ilişkin söylem yapılarının temelde aynı kalıplar üzerine kurulduğunu göstermektedir. Bu kalıplardan ilki "tarihe atıf" yapmaktır. Her üç olayda da benzer durumların daha önce yaşandığına dair ifadeler "cadı" olgusunun varlığına delil olarak sunulmuş ve olgunun gerçeklik ile bağı kurulmaya çalışılmıştır. Olayların gerçeklik ile bağının kurulmasında kullanılan bir diğer kalıp ise doğaüstü bir varlık olarak "cadı"nın üç olay da ortaya koyduğu eylem birlikteliği ve etkisidir. Gündelik hayatı sekteye uğratan bu eylemlerin temel etkisi korku ve dehşettir. Batılı "vampir" olgusu ile Osmanlı "cadı"sının ayrıştı̆̆ı temel noktalardan birisinin de bu eylem olgusu olduğu iddia edilebilir. "Cadı" her ne kadar "vampir" gibi ölüm sonrası hayata tekrar dönen bir varlık olsa da öldürerek ya da kurbanının kanı ile sonsuz hayata ulaşmak gibi eylem türleri sergilememektedir. Ele alınan üç olayda da yaşayanların ölümden sonra "hortlayan" bu varlıklara dair şahitlikleri de olayların gerçeklik bağının kurulduğu bir diğer unsurdur. Gerek olgunun tespitinde gerekse de aktarılmasında sürecin şahitlerin ifadeleri üzerinden gitmesi olayın gerçekliğinin önemli bir saç ayağını oluşturmaktadır.

Karaferye'de 1872 ve 1874 yıllarında ortaya çıktığı iddia edilen "cadı" olaylarına ilişkin dönemin mizah dergilerinin tavrını "söylence" karşısında sergilenen "bıyık altından gülme" ş̧eklinde tanımlamak mümkündür. Bu tavrın sebebi mizah ile ilgili tematik birer yayın olmaları ile açıklanabilir. Ancak bu açıklama kolaycı bir yaklaşımdır. Tanzimat sonrası Osmanlı aydınının benimsediği pozitivist düşünce, Karaferye olayları karşısında gerek mizah dergilerinin gerekse de diğer süreli yayınların yaklaşımını belirleyen temel unsur olarak kabul edilebilir. Kesin ve kanıtlanmıș bilgi üzerine 
bu düşünce çerçevesinde dönem periyodiklerine göre Karaferye olayı "söylence" ya da "batıl itikat"tan başka bir şey değildir.

Olayın gerçeklikten uzak oluşuna ilişkin tutumları dönemin mizah dergilerinin olay odaklı bir yaklaşım yerine olgunun toplumsal anlamı üzerine yoğunlaşmalarına sebep olmuştur. Bu durumun bir sonucu olarak dergiler söylemlerinin çatısını "geçimsiz, huysuz, kocakarı" tanımlamaları üzerine kurmuşlardır. Gerek Karaferye'de ortaya çıktığı iddia edilen olaya gerekse de bu olay etrafında "cadı" olgusuna aynı açıdan yaklaşan Tanzimat dönemi mizah dergileri "söylence" olarak kabul ettikleri olgunun halk inancı içerisinde tanımlanmış özelliklerini gündelik hayatta karşılaşılan durumlar ile bağdaştırmışlardır. $\mathrm{Bu}$ bağlamda kullanılan temel özellik "hortlama"dır. Diğer özelliklere nazaran bu özelliğin tercih edilmesinde "ölümden sonra hayata dönme" mantığının pozitivizm ile çelişmesi olduğu söylenebilir.

Gerçekliği ispata muhtaç olsa da "cadı" olgusu, Tanzimat dönemi mizah dergilerine göre 19. yüzyıl Osmanlı toplumunda farklı mecralarda karşılığı olan bir gerçekliktir.

\section{Kaynakça}

Abdülaziz Bey. Osmanlı Âdet, Merasim ve Tabirleri. yay. haz. Kâzım Arısan, Duygu Arısan Günay. İstanbul: Tarih Vakfı Yurt Yayınları, 1995.

Aycibin, Zeynep. “Osmanlı Devleti'nde Cadılar Üzerine Bir

Değerlendirme". OTAM 24 (2008), 55-70.

https://doi.org/10.1501/OTAM_0000000545

Basiret. "Şu vakıa-i garibe Selanik gazetesinde okunmuştur", Sayı: 1330, (10 Şaban 1291/21 Eylül 1874), 2-3. İ.B.B. Atatürk Kitaplığı Demirbaş No: NS0211. 
Berger, Peter L. - Luckmann, Thomas. Gerçekliğin Sosyal İnşası. çev. Vefa Saygın Ögütle, İstanbul: Paradigma Yayınları, 2008.

Boratav, Pertev Naili. 100 Soruda Türk Folkloru. İstanbul: Gerçek Yayınları, 1984.

Demirkol, Gökhan. “Tanzimat Dönemi Türkçe Mizah Dergilerinin "Mizah"ı Tanımlama Biçimleri (1870-1877)". Alay Kitabı, ed. Emine Gürsoy Naskalı. 23-59. İstanbul: Kitabevi Yayınları, 2019.

Demirkol, Gökhan. “Tanzimat Mizahının “Şarivari”leri: Şarivari Yada İbretnüma-yı Âlem (1871) ve Şarivari Medeniyet (1874)

Mizah Dergileri. CBÜ Sosyal Bilimler Dergisi 17/1, (2019), 265293. https://doi.org/10.18026/cbayarsos.514264

Diyojen. “Karaferyeden Mektub”, Sayı: 129, (5 Ağustos 1288/17 Ağustos 1872), 1-2. İ.B.B. Atatürk Kitaplığı Demirbaş No: NS0465.

Doğan, Cem. “Osmanlı Devleti'nde Cadı Avı Var mıydı? (Karşılaştırmalı bir İnceleme)”, Tarih Kültür ve Sanat Araştırmaları Dergisi 2/1 (2013), 218-240. https://doi.org/10.7596/taksad.v2i1.169

Düzdağ, M. Ertuğrul. Şeyhülislam Ebussuud Efendi Fetvaları Işı̆̆ında 16. Asır Osmanlı Yaşamı. İstanbul: Kapı Yayınları, 2012.

Hayal. Sayı: 91, (7 Ağustos 1290/19 Ağustos 1874), 2-3. İ.B.B. Atatürk Kitaplığı Demirbaş No: NS0787.

Hayal. Sayı: 99, (4 Eylül 1290/16 Eylül 1874), 2. İ.B.B. Atatürk Kitaplığı Demirbaş No: NS0787.

Hayal. Sayı: 125, (4 Kanunievvel 1290/16 Aralık 1874), 3. İ.B.B. Atatürk Kitaplığı Demirbaş No: NS0787. 
Söylence ile Gerçeklik Arasında: 19. Yüzyıl Osmanlı Mizah Basınında Karaferye Cadıları

Hayal. Sayı: 105, (25 Eylül 1290/7 Ekim 1874), 2. İ.B.B. Atatürk Kitaplığı Demirbaş No: NS0787.

Hülâsatü'l Efkâr. “Ifade-i Mahsusa”, (9 Temmuz 1290/21 Temmuz 1874), 1. İ.B.B. Atatürk Kitaplığı Demirbaş No: NS0855.

Işık, S. Yetkin. “Tırnova Cadıları Yahut Sözlü Kültürlerde Halk İnançlarının Siyasal Manipülasyonu”, Doğu Batı 84, (2018), 255-273.

Kırgi, Salim Fikret. Osmanlı Vampirleri. İstanbul: İletişim Yayınları, 2018.

Kiel, Machiel - Gara, Eleni “Karaferye”, Türkiye Diyanet Vakfi İslam Ansiklopedisi, 24/391-394, Ankara: TDV Yayınları, 2001.

Köhbach, Markus. "Ein Fall Von Vampirismus Bei Den Osmanen", Balkan Studies 20 (1979), 83-90.

Latife. "Kabristandan”, Sayı: 9, (9 Eylül 1290/21 Eylül 1874), 4. Hakkı Tarık Us Koleksiyonu Yer No: 0237/1.

Latife. Sayı: 10, (21 Eylül 1290/24 Eylül 1874), 4. Hakkı Tarık Us Koleksiyonu Yer No: 0237/1.

Latife. Sayı: 11, (16 Eylül 1290/28 Eylül 1874), 1-2. Hakkı Tarık Us Koleksiyonu Yer No: 0237/1.

Latife. Sayı: 13, (23 Eylül 1290/5 Ekim 1874), 2. Hakkı Tarık Us Koleksiyonu Yer No: 0237/1.

Mazower, Mark. Selanik: Hayaletler Şehri, Hıristiyanlar, Müslümanlar ve Yahudiler (1430-1950). çev. Gül Çağalı Güven. İstanbul: Yapı Kredi Yayınları, 2007. 
Medeniyet, "Selanik gazetesinden alındı", Sayı: 9, (10 Şaban 1291/21 Eylül 1874), 2-3. İ.B.B. Atatürk Kitaplığı Demirbaş No: NS1318.

Ortaylı, İlber. İmparatorluğun En Uzun Yüzyılı. İstanbul: İletişim Yayınları, 2001.

Redhouse, James W. Müntahabât-ı Lügât-ı Osmâniyye. haz. Recep Toparlı, Betül Eyövge Yılmaz, Yaşar Yılmaz. Ankara: Türk Dil Kurumu, 2016.

Redhouse, James W. Turkish and English Lexicon. İstanbul:

Amerikan Misyoner Şirketi, 1890.

Şark. "Okumalı da anlamalı Selanik gazetesi neler yazıyor", Sayı: 239, (10 Şaban 1291/21 Eylül 1874), 2. İ.B.B. Atatürk Kitaplığı Demirbaş No: NS1982.

Şark. Sayı: 252, (24 Eylül 1290/6 Ekim 1874), 2. İ.B.B. Atatürk Kitaplığı Demirbaş No: NS1982.

Şemsettin Sami. Kamus-i Türki. İstanbul: Çağrı Yayınları.

Takvim-i Vekayi. Sayı: 68, (21 Cemaziyelevvel 1249/6 Ekim 1833), 3. İ.B.B. Atatürk Kitaplığı Demirbaş No: NS2061.

Tiyatro. “Vay!..”, Sayı: 51, (11 Eylül 1290/23 Eylül 1874), 1-2. İ.B.B. Atatürk Kitaplığı Demirbaş No: NS2183.

Tiyatro. “Cadı !!!”, Sayı: 52, (14 Eylül 1290/26 Eylül 1874), 2-3. İ.B.B. Atatürk Kitaplığı Demirbaş No: NS2183.

Tiyatro. "Karaferyeden alınan telgrafnameler", Sayı: 52, (14 Eylül 1290/26 Eylül 1874), 4. İ.B.B. Atatürk Kitaplığı Demirbaş No: NS2183. 
Söylence ile Gerçeklik Arasında: 19. Yüzyıl Osmanlı Mizah Basınında Karaferye Cadıları

Ursinus, Von Michael. "Osmanische Lokalbehörden der frühen Tanzimat im Kampf gegen Vampire? Amtsrechnungen (masarıf defterleri) aus Makedonien im Lichte der Aufzeichnungen Makro Cepenkovs (1829-1920)", Wiener Zeitschrift für die Kunde des Morgenlendes. 82, (1992), 359374.

Yaltırak, Mehmet Berk. "Türk Kültüründe Hortlak-Cadı İnanışları", Tarih Okulu Dergisi 18 (2013), 187-232. http://dx.doi.org/10.14225/Joh346 
Gökhan DEMIRKOL 